\title{
The City of Guinga is Biographical
}

https://doi.org/10.21814/uminho.ed.51.4

Teresa Lima

Centro de Estudos de Comunicação e Sociedade, Instituto de Ciências Sociais, Universidade do Minho, Braga, Portugal https://orcid.org/0000-0001-8477-617X lima.teresa0@gmail.com

Zara Pinto-Coelho

Centro de Estudos de Comunicação e Sociedade, Instituto de Ciências Sociais, Universidade do Minho, Braga, Portugal https://orcid.org/0000-0001-6651-3720

zara@ics.uminho.pt

\section{Abstract}

Moved by the Brazilian musician Guinga composition "Meu Pai" (my father), we established a symbiotic relationship between the concepts of life (biography), place (city of Rio de Janeiro) and music. The analysis of "Meu Pai" is a synthesis and a pretext for reflecting on what art does to an artist and those who absorb it. In our theoretical framework, we rely primarily on James Carey (2009) and Gaston Bachelard (1957/1996). As a guide for this journey, we chose Guinga. He leads the journey. His circumstance takes us in an essay that has movement as its axis.

Keywords

biography, city, movement, music, place 
We will seek, in this article, to roam around three propositions: life (body that inhabits a specific and finite time and space), city (the polis with which life dialogues) and music (an aesthetic expression that suggests the conversation between the first two). The port of departure is the composition "Meu Pai" by the Brazilian musician Guinga.

The body is a movement fixed in gestures, form, substance, immateriality and emotion. The city is the streets, houses, monuments, sounds, flows and the lives that are sheltered in it or that it vomits. The city acquires meaning because its buildings (like fossils) keep information about the 1,000 lives that dwell in it. As a dialoguing being, the city knows and preserves. As a "memory of itself, the city offers itself to be penetrated and penetrates the memory of those who cross it, depositing a discontinuous thread of flows therein" (Bailly, 2013, pp. 74-75). When everything is already reduced to dust, the city's streets (like art), even if disfigured, retain reserves of memory in the stone and ground that make them. In music, both language and communication fit. Music is the time fixed in space, feeling and sublimating the unspeakable (beyond what is said). It is, says Cohen (1995), particularly effective in "stimulating a sense of identity, in the conservation and transmission of cultural memory and the sensual production of a place" (p. 435).

Jean Charnaux fuses music and city in the characterisation of Guinga (Grupo Sintonize, 2019). The musician confesses himself in the abyss because of the difficulty of musically theorising Rio's composer. Escaping the analytical explanations, he exemplifies the artist's genius with an experience of life witnessed in the city. He describes a moment in the middle of Rio de Janeiro, next to the Rio Sul underground runway, one of the busiest roads in the city, where Guinga decided to cross. "His eyes were on the right moment of the explosion between the milliseconds that separated life from death" (Grupo Sintonize, 2019, 00:25:21). Charnaux makes an association between the "insanity" of the act and the genius of Guinga, an artist who is not always understood, whose "melodic sequences disentangled themselves from the conventional pattern of normal composers of his time" (Grupo Sintonize, 2019, 00:26:58). He goes on, saying:

it was like a miracle worker who used music as a tool for a much greater transformation in human beings. It was perfection marked by the aesthetics of repetition of his own musical habits ( ...) for the normal human beings he was the mere insane that was walking in the opposite direction of life, as in that moment when crossing the busy street. (Grupo Sintonize, 2019, 00:27:20) 
We cannot always identify the exact moment when a reading, a song, a painting or a film change their status from something unknown to something essential. In Guinga, a musician from Rio de Janeiro, it is difficult to specify the detonator that made him indispensable. Appropriation has a bit of cannibalism. We do not know who that person is, we are not able to detail what he tries to say with his music, nor does that seem relevant at first glance. At this point, it is almost inevitable that we associate this (non) perception with the defence of the author by Foucault (1971/2002), extensively analysed by Agamben (2005/2007). That is, the absence of the author is, in fact, the first place in the discourse (Foucault, 1971/2002). However, what is important to underline is that we take Guinga work in our ears, in our brain and our feelings, appropriating the melody, the harmony and the words, that is, transforming the experience of hearing into our life experience or into a type of sensory experience that we savour for the first time. Bachelard $(1957 / 1996)$ attributes this connection to poetry. Dewey (1934/2008) speaks of "vital" or "integral" experience, which is also a process of communication:

because communication does not consist of announcing things ( ... ) but is a process that creates participation that makes what was isolated and singular common; and part of the miracle it performs is that, when communicated, the transmission of meaning gives body and definition to the experience, both of those who express it and of those who listen. (p. 275)

As Dewey (1934/2008) tells us, the work of art should not be confused with the product, a song, a painting. The work of art "takes place when the human being cooperates with the product so that its result is a pleasant experience because of its liberating and ordered properties" (Dewey, 1934/2008, p. 241).

\section{What Does the First Version of This Song Tell Us, When We Hear it Without Any Kind of Context?}

The composition "Meu Pai" appears on the album Canção da Impermanência (2017; see Pedrosa, 2017) as this project's first track. The author is Guinga, who dedicates it to his father. In this first approach, there is still no lyrics but only vocal singing exercises. On a second album (Avenida Atlântica, also from 2017), "Meu Pai" opens the work again, this time with lyrics (see Selo Sesc, 2017). What does the first version of this song tell us when we hear it without any kind of context? The music of Guinga wanders elegantly 
through insomnia territories. Even without knowing about his relationship with the city of Rio de Janeiro or how biographical his art is, this sentimental wandering attracts us through streets and alleys, which may be physical or emotional. Or both, in an indistinct whole. There is a lot of rail in the compositions, which we hear randomly. In "Meu Pai", there is a sense of a journey, which is intuitive and repeated. Vocalisation accentuates how much one feels and how little words can hold. However, in gaining lyrics and texture, in Avenida Atlântica, "Meu Pai" does not lose. As he says, in letters of his authorship, "the words dissolve in the mouth" (Ayer, 2020, 01:07:43). What was hidden comes to the surface with a touch of enchantment. For a foreigner of Guinga's music, life history or carioca geography, what seduces is the musicality of the words: Itaoca, Itararé, Inhaúma, Macaúba. Even without giving meaning to the words, better said, especially if we do not associate words and meanings, what attracts are these sounds, the exoticism of the words that resonate in a voice. It will take time to reach meaning. The idea of the path, which has a crossroads, is accentuated. After several hearing cycles, the lyric bares the being so much that we are amazed. After all, it is a simple story of someone who speaks of childhood memories associated with the father figure. For now, let us be admired. What other sensations does "Meu Pai" convey? Yes, a route that surrounds the city, to places that we do not know, but that we visualise mentally as clearly as childhood is, built-in fragments (a child does not have the perception of the whole, retains intermittently what she or he has fixed as a significant experience): at each curve a geographic and sentimental reference, from the church of São Roque to the corner of Baronesa. We do not know any of these spaces, but we have already experienced some sense of place, guided by the Guinga's musical atmosphere. Curious is this wandering if we think that there is no city without movement, that the body itself is movement (even if at rest) and that music is also characterised by movement. And what is life for Guinga? "Life is movement. While we are here talking, our whole body is working, the mitochondria are doing a thousand biochemical adventures" (Composição Escola de Música da UFRJ, 2020, 00:21:35).

\section{What Does a Song About a Vulgar Story Do to Its Listener?}

Canção da Impermanência is a kind of nonconformist acknowledgement. If "impermanence is the opposite of life" (tvBrasil, 2018b, 00:16:31), art is an attempt to resist finitude: art and affective ties. For the musician, "the feeling must go to some niche, there must be some deposit of feeling, of affection, of sensitivity, to fight against the impermanence of everything" 
(Composição Escola de Música da UFRJ, 2020, 00:22:15). The home-place may function as a sentimental and, in some way, a metaphysical repository. Home is, after all, the starting point, but also that the point of eternal return, in a kaleidoscopic mental becoming. If movement is necessary to return to it, the rest provides a point of permanence in time and space (Bennett, 2005). It is a sense of belonging, even if imagined or ethereal. It is the "communication place" of James Carey (2009).

As we mentioned above, the work opens with an allusion to a childhood figure, attesting to the weight and importance of the personal side in the artist's work. As Anna Paes (2019) says, "in her modus faciendi, the inspiration to compose comes not only from technical knowledge or the ability to listen but also from the ability to be moved by the events of life" (p. 43). To objectify in music and words what is lived is to fix memories. James Carey (2009) highlighted time (the place of memory) in ritual communication, making room for transmissive communication. The rituals (the memories shared by a community) build the identity, make us belong to a place, and help us say who we are. In "Meu Pai", nothing about Guinga's personal history seems relevant in the community or historical or social terms. It is the story of a soldier, of the places he travelled, of night surveillance to a water tank, preventing the liquid from being poisoned, a life that has nothing exceptional. However, when apprehended by a poet's sensitivity, a trivial case captures the immateriality of the communicative act. For Guinga, this story has meaning because it was told to him by his father. What he does is to give back that learning through a song attempting to make ties remain. Guinga was, for most of his artistic life, the author of his songs (and also of instrumental ones, although in a smaller number), leaving the lyrics for names as Paulo César Pinheiro and Aldir Blanc both highly regarded in the popular Brazilian music scene. Canção da Impermanência (see Pedrosa, 2017) is an almost exclusively a solo signature album, except "Doido de Deus" (see Pedrosa, 2017, track 17), which he shares with Thiago Amud. Guinga does not see himself as a poet and summarises:

I wrote a small letter, a tribute to my father, talking about things that only my family, me or them, would know. (...) I expressed a feeling for my father. A guy can say, "it doesn't have the least poetic value", f ... I did it for my father. (Ayer, 2020, 01:08:00)

That might be the meaning that Bailly (1992, as cited in Sheringham, 2017) had in mind when referring to the micro-stories that the city collects as a deposit of memories. 
How this emotion is expressed through art makes what is beyond language tangible, transforming, who knows, the lived experience, into something permanent, that is, in a work that does not leave anyone indifferent, incorporating new sensations to the initial experience that was intended to be shared. Isn't this where James Carey (2009) tries to touch when referring to communication and culture? What does a vulgar story do to its listener? Bachelard (1957/1996) says: "the image becomes a new being in our language, it expresses us by doing what it expresses, that is, it is both a becoming of expression and a becoming of our being" (p. 6).

\section{When the Space Becomes a Place}

Returning to our three initial propositions (life, city, music), we want now to detail the importance of place in Guinga's work, who claims to have Rio "mapped in the heart" (Vianna, 2018, 00:22:53). "Meu Pai" condenses a physical (geographic) map and a sentimental one, at the same time, which blend. For Guinga, "the landscape is inside, the landscape is not outside. You can see the most beautiful place in the world, but if you are depressed, it will not remind you of Eden. It will remind you of the descent into hell" (Zuppo, 2017,00:21:08). Ingold (1993) rejects the division between the inner and outer world, proposing, in turn, a relational dynamic between subjects and places. That is, after all, what arises from "Meu Pai": a musical landscape generated in movement and interaction. We can naturally point out the geographical coordinates enunciated by Guinga and recognise the emotions, stories and feelings with which both (the landscape and the musician) nourished themselves. For this reason, Jacarepaguá is not just a point on a topographic map in the suburbs of Rio de Janeiro. It is the origin of life. Born in the north zone of Rio de Janeiro, in Madureira, Guinga lived in Jacarepaguá. Suburban origins are always highlighted in the interviews he grants as part of his personal matrix. Other compositions reflect the importance of place. Suite Leopoldina (1999; see Gravadora Galeão, 2016) is a title dedicated to the mother, originally from this area of Rio de Janeiro. We can also name Dialetto Carioca (2007; see Brownlee, 2011) or Casa de Villa (2007; see Nóbrega, 2016) - double meaning of the childhood home and the influence of the composer Heitor Villa-Lobos - or Noturno Copacabana (2003; see Recovering Music Addict, 2011). This latest album reflects the composer's relocation from the north to the south of Rio de Janeiro in the 70s. It is a work that expresses the impact of a new urban geography on the author, who explains: "it is a tribute to angels and demons that inhabit this place" (Guinga, 2017, as cited in Paes, 2019, p. 47). 
Tuan (1977) guides us in the feeling we have for space, making it a place. If, as Bachelard (1957/1996) says, we know each other in time (the thread of the narrative), we objectify memory through space. "In its thousand alveoli, space retains compressed time. The space is for that" (Bachelard, 1957/1996, p. 19). The centrality of space dominates "Meu Pai", intending to overcome time. "Meu Pai" is an incessant search for the father figure (from shared experiences) in the concrete of the city: the Church of São Roque, wandering around. The song is a search and a reunion, the proof that what we live, does not exist only through imagination, nor is it lost over the years. The repetition in "Meu Pai" is expressed in the rhythm, melody and word, underlining the dichotomy between movement and fixation. With Julian Johnson (2015), we see that repetition ritualises the movement of place (place and space are a continuous process, which is never finished). The ritualisation then emerges from the experience gained in the relationship with space, which "Meu Pai" also echoes. After all, as Tuan (1975) states, "the place is a centre of meaning built by experience" (p. 152). Getting to know it takes time.

\section{"A Certain Beauty of Slow Music"}

We digress, along these lines, through the body, life and place as an organic and symbolic whole, based on a composition by the musician from Rio de Janeiro, Guinga. Another element is missing: the music. According to Johnson (2015), modernity in music stems from the city, "since this is the physical centre where music happens and where the network of relationships that music reproduces, updates and reshapes" is established ( $p$. 129). Being an art structured in time, it aspires to materialise in space. We present the concept of musical architecture or even the music partiture (physical configuration of the music) as an argument for this assumption. "What sensory organs and experiences make human beings able of having strong feelings for space and spatial qualities?" Tuan (1977, p. 23) asks. And about hearing, he says: "the sound itself can evoke spatial impressions (...) musicians refer to the "musical space"' (Tuan, 1977, p. 25).

Thiago Amud describes characteristics of spatiality in Guinga's music: "the guitar sometimes looks like the bell of a cathedral, it looks like it is in a catacomb, it resonates with a metaphysical depth" (Delírio Carioca, 2020, $00: 30: 14)$. Let us say that music is another form of language which transcends what the conventional linguistic code can achieve. "It is not that music refers to something unspoken but rather to the unspeakable" (Johnson, 
2015, p. 256). We look for Guinga's words: "music is beyond what you can define, any art is much beyond the palpable, in reality, the true art is in the impalpable" (Composição Escola de Música da UFRJ, 2020, 00:14:32). Like any code, music is made up of symbols and will require mastery of that language. However, formal learning is not a prerequisite for an artist to be an artist.

By associating discourse with sound and music, van Leeuwen (1999) distances himself from the functionalist view to arrive at meaning through social contexts. Therefore, music (like language) will be much more than the mastery of a code, to let itself be contaminated by life. "In other words, musical time can reflect the way time is lived in the world where music is made, as well as people's affective relationship to that time, whether they welcome it or fight it" (van Leeuwen, 1999, p. 57).

The family environment (what was heard on the radio, parents' musical taste, living with an uncle who played the guitar) is pointed out by Guinga as a determining factor in the education of the ear. When he was young (between 11 and 13), he started to compose, very influenced by bossa nova, which was emerging. Personal relationships (family and neighbourhood) were the ones that most deeply marked the musician. As a teenager, he met guitarist Hélio Delmiro listened to Garoto's compositions, and these influences seem to have been fundamental. In this cultural environment, there was an incursion into formal learning of music, which he did not continue. Guinga does not know how to read or write music. His creations arise from a physical relationship with the guitar - Roendopinho (2014; see Pedrosa, 2015) is the suggestive name of one of his works - and a spiritual one with the musical entity itself. Orality is, therefore, the author's primary resource. In other words, he listened to music and translated it on the guitar. "This listening involves the transposition to the guitar of sounds that are sometimes orchestral and pianistic, generating particular ways of building chords" (Paes, 2019, p. 44). That matches extraordinarily with James Carey's (2009) approach to the conversation as the core of the whole communicative act and our foundation as social beings. Carey draws on Ancient Greece (the small conversation groups who discussed the life of the polis) to define ritual communication (whose symbols crystallise and renew in the community). Here, with Guinga, the artist dialogues with the city and, through it, with his memories, using orality as a basis and the body as the tool at his disposal. And what dialogue is this? "A certain beauty of slow music" (Saraiva, 2014, p. 202), Guinga explains to Chico Saraiva. He elaborates: "also, at the speed of a Ferrari, you don't see the landscape, you take Niemeyer, and you don't see Rio de Janeiro. With a slow car, you can enjoy the landscape more" (Saraiva, 2014, p. 198). 
Interesting in Guinga's interview with Chico Saraiva (part of a master's dissertation, in written and multimedia format) is the way the composer describes the path that he follows from thought to guitar (Saraiva, 2020). In the conversation, he tries successively to play a song, finding himself invariably dissatisfied with what he manages to achieve. There seems to be an impossibility between what one feels (the music in someone's head) and what one can perform, that is, the way it reaches the guitar. That is another obsessive search, with a desire for reunion and fixation.

Because Guinga is a musician who composes with the guitar in his hands, there is clear physical incorporation between thought, emotion, body and object. The guitar language is a theme that cuts across musical literature, and Guinga has not escaped this approach. It has to do with the mechanical component of the instrument, which lends itself to composition. Chico Saraiva, relying on ethnomusicology, refers, simultaneously, to a cultural idiom, that is, to the different characteristics that the same instrument acquires, in different socio-cultural contexts. Let us listen to Guinga: "the guitar is in the hands, but the head belongs to the popular composer. It is his feeling, his sadness and his joys" (Saraiva, 2014, p. 158).

Guinga seems to be above this ethnicity, as he absorbs elements from various popular Brazilian musical influences (baião, frevo, modinha), combining their different musicality with currents of European classical music (Debussy), Brazilian music (Villa-Lobos) and even traditional American jazz music:

His intention seems to be to integrate the rhythmic stimuli - which from its most fertile birthplace, the African, offers the world its own poetry - to the melodic-harmonic stimuli - forged throughout the history of European music - which in the eyes of the popular musician is associated with the "poetic". (Saraiva, 2014, p. 198)

\section{And the Author? What Does His or Her Life Matter to the Work of Art?}

Having presented our initial concepts, let us add "Meu Pai" to this pie. It is a totally autobiographical song, which translates the songwriter, unveils how these songs are created (the vocal singing exercises that accompany the guitar), is part of a biographical album of someone on a solitary journey, wandering through childhood memories, interpellating the city. Does the 
fact that the first published version of "Meu Pai" has no lyrics make it a song? The title alone allows us to perceive "Meu Pai" as a story attached to the melody even without the words. van Leeuwen (1999) sets the scene in these terms: "in speech and song, words and melody can both express similar or different meanings" (p. 79). As Chico Saraiva (2014) explains, "the song composer uses his voice, in different degrees of interaction with the instrument, to outline a musical gesture that fits voice and instrument in the search for a melody with a sense of song" (p. 90).

Moreover, what does "Meu Pai" suggest to a listener unaware of these considerations? The call of Guinga' s voice in "Meu Pai" is profound. We would dare to affirm that the poetic reach of this song arises from a symbiosis between voice, guitar and interpretation, like an old song that wanders through time immemorial, with no past, no future. The project Canção da Impermanência has a lonely and intimate beauty as if it were an inner voice or a voice heard in the distance. Avenida Atlântica works as a revelation: that of the word. And in the version of the Tom Jobim Orchestra (see EMESP Tom Jobim, 2020), it is an exuberance. The city is offered those words. Everything is opened and announced, like a celebration. Guinga's interpretation is no longer confessional but an announcement.

The Guinguian delirium is so untied with formulas that it is safe to say: "Guinga had a song. I wrote Variação first. Then Guinga made 'Meu Pai'. A crooked musical duo is like this: it starts with the after, it ends with the before" (Amud, 2019b). Variação was the lyrics made by Thiago Amud for the melody of Guinga, who only later titled it "Meu Pai" and filled it with words, as we know. The duo presented both versions at Guinga's 50-year-old concert (tvBrasil, 2018a), establishing a disconcerting dialogue between both. If two different stories are told formally, the melody carries such a lonely identity that we are almost led to believe it is a monologue. Guinga talks to the city, his father and childhood memories. Thiago Amud fills the melody with an interpellation to the origin, creating a dichotomy between emptiness and life, confusing it with the craft of creation or, as he wrote in Variação, "the lyrics of the song that lay under the pulse" (Amud, 2019a, 00:02:49). We can guess a conversation with his own gift of composing and the visit of music in his life story, which he sees as a kind of big bang, the beginning of everything. There is a movement of wings, atoms, and sea in these lyrics, which generate clairvoyance. There is a return to an initial and transforming place in both, attempting to integrate it and make it permanent. 
Having reached this point, we cannot avoid the question that has haunted us (albeit subliminally) throughout the entire essay: what about the author? What does his life matter to the work of art? What does it put out of his experience in the poem? If the biography (life story) is as central as we believe, how does it participate in the work? What contribution can it provide to understand the work of art?

\section{There is No Communication and Culture Without a Biographical Subject}

At the beginning of this text, we wrote that we rely on theoretical references but that, essentially, we are guided by Guinga. "Meu Pai"'s analysis and the realisation of the conversation between its lyrics and the Variação of Amud necessarily send us back to James Carey (2009), our initial reference. The dialogue between the two musicians is a condition of their life experiences, in a relationship where the self and the surrounding community enter. For Guinga, there is a fusion between the city and childhood memories. In Thiago Amud, the external stimulus is Guinga's melody, which he materialises in something new, another discourse. We cannot ignore Agamben's (2005/2007) theory either, in how he interprets the death of the author by Foucault. The impulse towards creation can be so intense that the author throws himself into his own communicational act. In doing so, he dies a little, and he disappears to the point of giving rise to other discourses. But his absence is what makes him remain in the work.

Like Foucault (1971/2002), we reiterate the author's absence in the sense that he will have to disappear for the work to be born. However, we do not stop in the functionalism of language, to the point of transforming it into something aseptic. There is a place (that of discourse, we believe) of mediation between the individual and the context surrounding him or her, which creates reality. No, it is not a representation of reality but the world built by the symbolic exchanges of discourse. And, yes, we return to the starting point: ritual communication, established by conversation. "Meu Pai" and Variação arise from this convergence (and confrontation) between the place of the subjective, the social context and the interpretations that are played in the exchange of artistic experiences between two authors. We can argue that starting from the same melodic basis, the two went through different paths, and what is valid is what each one presents (and represents) through a semiotic resource. Or, in a deeper sense, we can also choose the relational side of communication, which is also, and 
ultimately, what builds a life. It may be that it is as postulated by Agamben (2005/2007) when he affirms that "a subjectivity is produced where the living being, when finding a language and putting it into play without reservation in a gesture exhibits its own irreducibility to it" (p. 57).

As culture is an object of study in communication, how can we ignore the importance of biography within this area of knowledge? For this reason, we bring Guinga's life (the tribute to his father) to the field of communication, not only because of the work he produced but because that work is the person. Here, we are not referring to the factual sequence of the lived, but to the discourse that gives it meaning:

deeper than biography, hermeneutics must determine the centres of destiny, detaching the history of its connective temporal tissue without action on our destiny. More urgent than determining the dates is, for the knowledge of intimacy, the location in the spaces of our intimacy. (Bachelard, 1957/1996, p. 19)

\section{"Who Am I in the City?"}

Taking the relationship between the artist's experience and its correspondence to the work of art for granted seems so obvious that it may not be worth thinking about it. It is precisely in this evidence that the biography stands. Like the body we inhabit in this world, the city is built. Roads are arteries; urban centres are brains, horizontality, verticality and spatial orientation (Tuan, 1977). Everything is done by analogy to our body. The city (life) is tattooed by the communicative acts that cross it and multiply it in successive versions of itself. It is as full of wonder and horrors as the human being is beautiful and imperfect. We (and the cities we populate) are the product of these communicational relationships, of the discourses that create the world (Carey, 2009). In this complex whirlwind, the artist seeks who it is, not what it is (Kristeva \& Collins, 2001). The poet acts on the polis; his work is always a way of doing something, expressing what cannot be contained. As such, it is imbued with an aesthetic sense. This drive is a way of constructing its own identity, based on its position before its surroundings, either by difference or identification. In the end, the objective (albeit implicit) will always be a matter of belonging (or not) to a place. With the place, we mean the house, an aesthetic current, the look of someone you love, its subliminal existence on the cobblestones. Identity (or a sense of belonging) only exists vis-a-vis the other. 
The approach of the city as an identity space is an achievement of modernity. "The city streets become the stage for a meeting between the self and the other, individual conscience and figures who look at their confines and perplexities" (Sheringham, 2017, p. 3). According to Sheringham (2017; and so it is with "Meu Pai"), the city will be for the poet the place where the question "who am I in the city?" reverberates in art. From a space segmented by streets, locations, geographic landmarks, the city acquires, with these poetic invocations, the status of an organic whole, which is the same as saying a body, another body with which one dialogues.

For the artist, life does not fit within itself. That is why the work is born. Guinga expresses this truth as follows: "I make music because if I didn't, I would be a little dead, I would feel sick" (Canelas, 2011, 00:19:05). It will not matter that much if it makes him think of an audience, but rather because it establishes an inevitable bridge between individual thought and public space. It turns out that this encounter of the self with the worlds (his lived experience and that of others), putting himself into play through an aesthetic language (music, poetry...), proves that there is no communication and culture without a biographical subject.

Translation: Zara Pinto-Coelho

\section{Acknowledgements}

This work is supported by national funds through FCT - Fundação para a Ciência e a Tecnologia, I.P., under project UIDB/00736/2020 (base funding) and UIDP/00736/2020 (programmatic funding).

\section{References}

Agamben, G. (2007). Profanações (S. J. Assmann, Trans.). Boitempo. (Original work published 2005)

Amud, T. (2019a, March 24). Gravado ao vivo no teatro BNDES (RJ) [Video]. Facebook. https:// www.facebook.com/watch/?v=279612639645011

Amud, T. (2019b, March 24). Variação / Meu Pai - Guinga e Thiago Amud - ao vivo (trecho) [Post]. Facebook. https://m.facebook.com/thiagoamud/videos/2152681705022454/

Ayer, M. (2020, October 24). Guinga: "Aldir Blanc não errava" [Video]. YouTube. https://www. youtube.com/watch?v=92p_3Se4z1s

Bachelard, G. (1996). A poética do espaço (A. de P. Danesi, Trans.). Martins Fontes. (Original work published 1957) 
Bailly, J.-C. (2013). La phrase urbaine. Seuil.

Bennett, T. (2005). Home. In T. Bennett, L. Grossberg, \& M. Morris (Eds.), New keywords: A revised vocabulary of culture and society (pp. 162-164). Blackwell Publishing.

Bruce Brownlee. (2011, April 30). guinga - 1. di menor [Video]. YouTube. https://www.youtube. com/watch?v=2KXzC2XkN8M\&list=PLTI7tdPHvKRIHEplLkLHORVjKW-eVQezK

Canelas, E. (2011, April 3). Entrevista a Guinga [Interview]. RTP. https://arquivos.rtp.pt/ conteudos/entrevista-a-guinga/

Carey, J. W. (2009). Communication as culture: Essays on media and society. Routledge.

Cohen, S. (1995). Sounding out the city: Music and the sensuous production of place. Transactions of the Institute of British Geographers, 20(4), 434-446. https://doi.org/10.2307/622974

Composição Escola de Música da UFRJ. (2020, September 8). Bate-papo sobre composição: Guinga [Video]. YouTube. https://www.youtube.com/watch?v=qcRuvH36Gel

Delírio Carioca. (2020, June 10). Guinga - Delírio Carioca [Video]. Youtube. https://www.youtube. com/watch?v=o_S17gadPzA

Dewey, J. (2008). El arte como experiencia (J. Claramonte, Trans.). Paidós. (Original work published 1934)

EMESP Tom Jobim. (2020, April 25). Meu Pai | Tom Jobim visita Guinga [Video]. YouTube. https:// www.youtube.com/watch?v=CVOZom8qG08

Foucault, M. (2002). O que é um autor? (5th ed., Vol. 6). Vega. (Original work published 1971)

Gravadora Galeão. (2016, October 31). Guinga - Suíte Leopoldina [1999] (Álbum Completo) [Video]. YouTube. https://www.youtube.com/watch?v=q9WLiCKaaQs

Grupo Sintonize. (2019, August 1). Congresso Guinga - Mesa-redonda Características estéticas e culturais da produção de Guinga [Video]. YouTube. https://www.youtube.com/watch?v=UtjicMz8Ow

Guinga - Tema. (2017, May 4). Doido de Deus [Video]. YouTube. https://www.youtube.com/ watch?v=qdX4QJX8G44

Ingold, T. (1993). The temporality of the landscape. World Archaeology, 25(2), 152-174. https:// doi.org/10.1080/00438243.1993.9980235

Johnson, J. (2015). Out of time: Music and the making of modernity. Oxford University Press.

Kristeva, J., \& Collins, F. (2001). Hannah Arendt: Life is a narrative. University of Toronto Press. https://doi.org/10.3138/9781442675605

Paes, A. (2019). A assinatura musical de Guinga: Memória, história e identidade. In T. L. Nicolau (Ed.), Anais festival de música contemporânea brasileira (Vol. 6, pp. 37-54). FMCB. https://fmcb. com.br/wp-content/uploads/2020/04/ANAIS-FMCB-6_AF.pdf 
Pedro Nóbrega. (2016, July 27). Guinga - Casa de Villa (2007) [Video]. YouTube. https://www. youtube.com/watch?v=YKOKwxewzuM

Pedrosa, A. (2015, November 15). Guinga - Roendopinho [2014] [Video]. YouTube. https://www. youtube.com/watch? $v=$ WkyOWM2YMwc

Pedrosa, A. (2017, September 17). Guinga - Canção da Impermanência [2017] [Video]. YouTube. https://www.youtube.com/watch?v=z4uLsR4X6K8

Recovering Music Addict. (2011, November 23). Guinga - Noturno Copacabana [Video]. YouTube. https://www.youtube.com/watch?v=wYk-Mj7wQ98

Saraiva, C. (2014). Violão-canção: Diálogos entre o violão solo e a canção popular no Brasil [Master's thesis, Universidade de São Paulo]. Biblioteca Digital USP. http://www.teses.usp.br/ teses/disponiveis/27/27158/tde-17122014-095449/

Saraiva, C. (2020, November 21). 46. Guinga e Chico Saraiva | 6.5 - uma coisa poética [Video]. YouTube. https://www.youtube.com/watch?v=Js6WAfNvGmc

Selo Sesc. (2017, September 12). Avenida Atlântica | Guinga + Quarteto Carlos Gomes | Álbum Completo | Selo Sesc [Video]. YouTube. https://www.youtube.com/watch?v=Fc9SJZb8Jt4

Sheringham, M. (2017). Perpetual motion: Studies in French poetry from surrealism to the postmodern. Modern Humanities Research Association. https://doi.org/10.2307/j.ctv16kkz7n.11

Tuan, Y.-F. (1975). Place: An experiential perspective. Geographical Review, 65(2), 151-165. https://doi.org/10.2307/213970

Tuan, Y.-F. (1977). Space and place: The perspective of experience. University of Minnesota Press.

tvBrasil. (2018a, May 4). Guinga celebra 50 anos de carreira [Video]. YouTube. https://www. youtube.com/watch?v=08d2To9YELU

tvBrasil. (2018b, May 4). Sem censura recebe Guinga [Video]. YouTube. https://www.youtube. com/watch?v=QkleApu4R6I

van Leeuwen, T. (1999). Speech, music, sound. Palgrave.

Vianna, L. F. (2018, May 18). Guinga. Rádio Batuta. https://radiobatuta.ims.com.br/programas/ estudio-batuta/guinga-2

Zuppo, D. (2017, August 17). Retratos de artista: Bate-papo com Guinga [Video]. YouTube. https:// www.youtube.com/watch?v=6buxw3Lb-Gk 